Е. С. Рапацевич]. - Минск : Современное слово, 2001. - 928 с. 9. Сохор А. Социологические проблемы музыкального восприятия / А. Сохор // Вопросы социологии и эстетики музики : [сборник статей]. - Т. 1. Ленинград : «Советский композитор». - 1987 - С. 89-120. 10. Тянь Ли. Сравнительное изучение международного мультикультурного музыкального образования [Электронный ресурс] / Тянь Ли // Образование и профессионализм. - № 21 (697). Режим доступа : http:/www.cnki.net 11. Фролов И. Т. Единство и своеобразие культуры / И. Т. Фролов // Красная книга культуры [Сост., подгот. текста и предисл. В. Рабиновича]. - Москва : Искусство, 1989. - 423 с. 12. Хуан Чжэнцзе. Мультикультурное образование: подход к учебным планам [Электронный ресурс] / Хуан Чжэнцзе, Ян Сиуе // Поликультурное образование. - Тайвань. - 1993. - № 3. - С. 3-17. Режим доступа : http:/www.docin.com/p-141049150.html\&endPro=true $\quad$ 13. Хуторской А. В. Ключевые компетенции как компонент личностно ориентированной парадигмы / А. В. Хуторской // Народное образование. - 2003. - № 2. - С. 55-62. 14. Чжэн Тю Юе. Поликультурное образование [Электронный ресурс] / Чжэн Тю Юе // Режим доступа : http:/www.docin.cjm/p 191795369.html

Катерина Коновалова

\title{
МЕТОДОЛОГІЧНІ ПІДХОДИ ДОСЛІДЖЕННЯ ПРОФЕСІЙНОЇ КУЛЬТУРИ МАЙБУТНІХ ВИХОВАТЕЛІВ
}

Коновалова К. І. Методологічні підходи дослідження професійної культури майбутніх вихователів.

У статті розглянуто сучасні методологічні підходи до формування професійної культури майбутніх фахівців спеціальності «Дошкільна освіта» в умовах вищого педагогічного закладу. Розкрито сутність поняття «методологія», «підхід». Проаналізовано основні методологічні підходи до професійної культури майбутніх вихователів дошкільних навчальних закладів. Виокремлено та охарактеризовано культурологічний, системний, особистісно зорієнтований, синергетичний, аксіологічний, компетентнісний підходи до професійної культури майбутніх вихователів.

Ключові слова: методологічний підхід, професійна культура, майбутні вихователі, професійна підготовка, вища освіта, вищий педагогічний заклад, фахівець спеціальності «Дошкільна освіта».

Коновалова Е. И. Методологические подходы исследования профессиональной культуры будущих воспитателей.

В статье рассматриваются современные методологические подходы к формированию профессиональной культуры будущих специалистов по специальности «Дошкольное образование» в условиях высшего педагогического учреждения. Раскрыта сущность понятия «методология», «подход». Проанализированы основные методологические подходы к профессиональной культуре будущих воспитателей дошкольных образовательных заведений. Выделены и охарактеризованы культурологический, системный, личностноориентированный, синергетический, аксиологический, компетентностный подход к профессиональной культуре будущих воспитателей.

Ключевые слова: методологический подход, профессиональная культура, будущие воспитатели, профессиональная подготовка, высшее образование, высшее педагогическое 
заведение, специалист направления «Дошкольное образование».

Konovalova K. I. Methodological approaches of research of future preschool teachers' professional culture.

In the article modern methodological approaches to formation of professional culture of future experts in speciality «Preschool education» at higher pedagogical institutions are considered. The content of the terms «methodology» and «approach» has been explained. The main methodological approaches to professional culture of future preschool teachers are analysed. The article presents methodological approaches (cultural, systematic, learner-centered, synergetic, axiological, competency) to the professional culture of future preschool teachers.

Key words: methodological approach, professional culture, future pre-school teachers, training, higher education, higher pedagogical institution, expert in specialty «Preschool education».

Стрімкі зміни, які відбуваються в різних галузях життя, розвиток нових освітніх парадигм, піднесення пріоритету гуманізації суттєво вплинули на вищу освіту України. Невід’ємність вищої освіти від ситуації, іiі інтеграція в різні суспільні сфери висуває необхідність переосмислення методологічних підходів дослідження професійної культури майбутніх вихователів у вищому педагогічному закладі. Варто відзначити, що від рівня сформованості професійної культури фахівців спеціальності «Дошкільна освіта», їх здатності до постійного особистого та професійного зростання, залежить якість освіти дітей дошкільного віку, їх підготовленість до життя.

Сучасному дошкільному навчальному закладу необхідний фахівець, який забезпечуватиме гармонійний розвиток особистості дитини, що визначено пріоритетним у Базовому компоненті дошкільної освіти. Виникає потреба саме в гуманістично спрямованих та конкурентоспроможних фахівцях спеціальності «Дошкільна освіта», які готові кваліфіковано здійснювати педагогічну діяльність в умовах дошкільного навчального закладу та досягати високого професійного рівня.

Стратегія сучасної системи вищої освіти полягає у професійній підготовці фахівців нового рівня, здатних до професійної самореалізації, самовираження та саморозвитку. Актуальність дослідження формування професійної культури майбутніх вихователів як необхідної якості зумовлена законом України «Про освіту», оновленому законі України «Про вищу освіту», Концептуальних засадах та напрямках розвитку вищої освіти в Україні, Державній національній програмі «Освіта» («Україна XXI століття»), Національній доктрині розвитку освіти.

У Державній національній програмі «Освіта» («Україна XXI століття») акцентовано увагу на підготовку нової генерації педагогічних кадрів, підвищення їх професіонального та загальнокультурного рівня.

Важливими шляхами реалізації ідей гуманістичної парадигми освіти є впровадження методологічних підходів до професійної культури майбутніх вихователів дошкільних навчальних закладів. Методологічні підходи дозволять у єдності, наступності та послідовності сформувати професійну культуру майбутніх вихователів, сприятимуть зростанню освіченості, розвитку творчості.

Проблеми методології педагогіки розглянуто в роботах С. Гончаренка, М. Данилова, В. Загвязинського, В. Краєвського, Ю. Кушнера, А. Новікова, Д. Новікова, Г. Рузавіна.

В останні роки професійно-педагогічна культура досліджується 3. Абросимовою,
К. Абульхановою-Славською,
С. Архангельським,
О. Барабанщиковим,
В. Беніним,
$€$ Є. Бондаревською,
Г. Васяновичем,
М. Віленським,
В. Гриньовим,
I. Зарецькою, 
Г. Звездуновою, I. Зимньою, I. Ісаєвем, Н. Кузьміною, Є. Левановою, Л. Машиною, А. Міщенко, В. Серіковим, О. Силяєвою, В. Сластьоніним, Н. Тарасевич, Є. Шияновим, В. Щербаковою та ін. Окремо присвячені дисертаційні дослідження Д. Качалова, В. Новікової, Т. Сидоренко, Я. Черньонкова щодо формування професійної культури педагога.

Наукові дослідження проблем формування професійної культури грунтуються на положеннях педагогіки культури (С.Гессен, І. Зязюн), філософії культури (П. Гуревич, М. Каган, В. Межуєв, С. Франк, Е. Ільєнков). Особливе місце належить працям науковців, у яких досліджувалася проблема формування професійної культури у філософськоісторичному (А. Арнольдов, Н. Злобін, Л. Коган) та соціологічному (Л. Іонін, В. Межуєв, П. Струве, Т. Ойзерман) напрямках.

Формування професійної культури майбутніх вихователів в освітньому процесі вищої педагогічної школи досліджувалося на основі культурологічного (Л. Бенін, В. Біблер, Є. Бондаревська, Л. Ісаєв, Л. Коган, В. Сластьонін, А. Флієр), системного (А. Авер'янов, В. Афанасьєв, I. Блауберг, В. Беспалько, Д. Гвишиані, Ю. Конаржевський, Н. Кузьміна, В. Садовський, Є. Юдін), особистісно зорієнтованого (Ю. Бабанський, І. Бех, О. Бондаревська, І. Дичківська, І. Зязюн, І. Котов, І. Кон, В. Лутай, О. Пєхота, О. Пометун, О. Попова, П. Решетніков, В. Сєріков, С. Сисоєва, Г. Селевко, А. Фурман, І. Якиманська), аксіологічного (І. Бех, Л. Бенін, Г. Вижлецов, Б. Гершунський, В. Ільін, Л. Ісаєв, В. Сластьонін), синергетичного (В. Аршінов, В. Бранський, В. Віненко, О. Князева, В. Кремень, І. Пригожин, Н. Таланчук, М. Федорова, Г. Хакен), компетентісного (І. Зимня, А. Маркова, Н. Селезньова, А. Хуторський, С. Шишов) підходах.

Незважаючи на багатоаспектність наукових досліджень, вивчення методологічних підходів формування професійної культури майбутніх вихователів потребує спеціального дослідження. $€$ потреба у методологічному осмисленні підходів, що уможливить підвищення ефективності здійснення професійної підготовки майбутніх вихователів, формування їх професійної культури. Мета статmі - проаналізувати методологічні підходи дослідження професійної культури майбутніх вихователів спеціальності «Дошкільна освіта».

Методологія як наука розроблялася в рамках філософії, тому доцільно звернутися до аналізу даного поняття у філософських словниках. Так, філософський енциклопедичний словник визначає поняття «методологія» (від метод і грецьк. - слово, поняття, пояснення) як «систему принципів і способів організації, побудови теоретичної і практичної діяльності, а також вчення про цю систему» [10, с. 365]. Поглиблений зміст окресленого поняття надає філософський словник, у якому «методологія» $\epsilon$, по-перше, сукупністю пізнавальних засобів, методів, прийомів, які використовуються в певній науці та, по-друге, галуззю знання, що вивчає засоби, передумови i принципи організації пізнавальної i практичноперетворюючої діяльності.

У педагогічній науці поняття «методологія» (від метод і грецьк. - вчення) тлумачиться як «сукупність прийомів дослідження, що застосовуються в певній науці; як учення про методи пізнання та перетворення дійсності» [2, с. 207]. Доповнює визначення словник професійних термінів, у якому «методологія» (від грецьк. methodos - шлях дослідження i logos - поняття, вчення) визначена як «вчення про структуру, логічну організацію, методи та засоби діяльності; вчення про принципи побудови, форми і способи наукового пізнання, а також сукупність методів, використаних у якій-небудь науці» [1, с. 166].

У науковій літературі з методології педагогіки наявні різні погляди щодо пояснення поняття «підхід». У загальнонауковому розумінні поняття «підхід» означає «сукупність 
прийомів, способів» [2, с. 545]. Словник основних понять методології визначає підхід, 3 одного боку, як певний вихідний принцип, вихідну позицію, основне положення чи переконання (цілісний, комплексний, системний, синергетичний та ін.), а з іншого, - напрям вивчення предмета дослідження (історичний, логічний, змістовий, формальний та ін.). Г. Селевко тлумачить підхід як методологічну орієнтацію педагога, яка спонукає до використання певної сукупності взаємопов’язаних ідей, понять і способів педагогічної діяльності [6, с. 69].

Здійснивши аналіз філософської та психолого-педагогічної літератури з проблеми формування професійної культури майбутніх вихователів, виокремлюємо такі методологічні підходи: культурологічний, компетентнісний, системний, особистісно зорієнтований, синергетичний та аксіологічний.

За визначенням Л.Ісаєва, за культурологічного підходу під проблемами педагогічної освіти розуміється активне освоєння педагогічних теорій, цінностей, технологій, оволодіння спеціальними знаннями, освоєння технології навчання i виховання, загальною та професійно-педагогічною культурою. Урахування культурологічного підходу забезпечить особистісний розвиток майбутніх фахівців, творчу самореалізацію педагога у професійній діяльності, вихід за межі нормативної діяльності, здатність створювати і передавати цінності [3, с. 6-18].

Проблема формування професійної культури майбутніх вихователів у контексті вищої педагогічної освіти повинна розглядатися із синергетичного підходу. Згідно з дослідженням В.Кременя, синергетичний підхід розгортає сукупність теоретичних знань як цілісність, унаслідок чого ми маємо можливість поєднати різні дисципліни, виробити нові шляхи осмислення реальності. Холістичність, яка включена в синергетику, «встановлює правила формування когерентного, внутрішньо узгодженого цілого із різнорідних хаотичних елементів, правила їх кооперації, співробітництва, взаємодії, правила нелінійного синтезу простогоу складне, виникнення синергії» [7, с. 16]. Сутність синергетичного підходу полягає в тому, що розвиток особистості в будь-якій сфері діяльності треба розглядати як саморозвиток. В. Кремень підкреслює виключну унікальність синергетичного підходу у можливості здійснення діалогу, творчості, індивідуального шляху розвитку особистості [7 с. 266-273].

I. Блауберг визначає системний підхід як один із методологічних напрямків сучасної науки. Системний підхід пов'язаний із вивченням і конструюванням об’єкта як певної системи. Такий підхід дозволяє цілісно розглядати формування професійної культури майбутніх вихователів під час здійснення їх професійної підготовки. Згідно з І. Блаубергом, основними завданнями системного підходу є розроблення змістових та формальних засобів дослідження об’єктів як систем; побудова узагальнених моделей систем і моделей різних класів та властивостей систем, включаючи моделі динаміки систем, їх цілеспрямованої поведінки, розвитку, ієрархічної побудови, процесів керівництва в системах; дослідження методологічних основ різних теорій систем.

Згідно з особистісно зорієнтованим підходом в центрі уваги знаходиться індивід і його особливості. Г. Селевко визначає особистісно-орієнтований підхід як створення сприятливих умов для особистісного зростання як педагога, так і учня. Особистісноорієнтований підхід передбачає методологічну орієнтацію вихователя в педагогічній діяльності, що дозволяє за допомогою опори на систему взаємопов'язаних понять, ідей, способів дій забезпечувати і підтримувати процеси самопізнання, самореалізації особистості дитини, розвитку неповторної індивідуальності. Окреслений підхід передбачає таку організацію діяльності, за якої особистість розкриває свої можливості, творчі здібності [6]. 
Особливу роль у формуванні професійної культури майбутніх вихователів відіграє компетентісний підхід, який, згідно з позицією Є. Когана, $є$ принципово новим і вимагає перегляду ставлення до позиції педагога, до навчання учнів. У словнику з педагогіки поняття «компетентність» означає «особистісні можливості посадовця і його кваліфікація (знання, досвід), що дозволяють брати участь у розробленні певного кола рішень або самостійно вирішувати питання, завдяки наявності певних знань, навичок» [9, с. 133]. І. Зязюн визначив компетентність у соціально-педагогічному контексті як екзистенціальну властивість людини, продукт власної життєтворчої активності. Словник іншомовних слів розглядає компетенцію (лат. competentia, від compete - взаємопрагну; відповідаю, підходжу) як коло повноважень якої-небудь організації, установи або особи; коло питань, в яких дана особа має певні повноваження, знання, досвід. На думку О. Лєбедєва, компетентнісний підхід передбачає сукупність загальних принципів визначення цілей освіти, добору змісту освіти, організації освітнього процесу та оцінки освітніх результатів. А. Маркова до компетентності педагога відносить високий рівень педагогічної діяльності і спілкування, наявність професійної позиції, психологічні якості, професійні знання та вміння. Завдяки цьому реалізується особистість педагога [4].

Відповідно до аксіологічного підходу людина визнається вищою соціальною цінністю. Сутність аксіологічного підходу полягає у формуванні у майбутніх вихователів загальнолюдських і професійних цінностей. В. Сластьонін, Г. Чижакова пояснюють цінності як специфічні утворення у структурі індивідуальної свідомості, що є ідеальними зразками та орієнтирами діяльності особистості й суспільства [8, с. 100]. В. Сластьонін, І. Ісаєв, $€$. Шиянов одним із провідних завдань даного підходу вбачають виявлення гуманістичної сутності науки, ставлення до людини як до суб’єкта пізнання, спілкування і творчості, розвитку гуманістичної сутності людини.

Підвищення якості професійної підготовки майбутніх вихователів спеціальності «Дошкільна освіта» потребує впровадження провідних методологічних підходів, що в результаті посилить акцент на формування професійної культури. Результати нашого дослідження дозволили виокремити методологічні підходи. Серед них- системний, культурологічний, особистісно зорієнтований, компетентнісний, синергетичний, аксіологічний. Окреслені підходи, які найбільше відповідають формуванню професійної культури майбутніх вихователів, забезпечують вибір стратегії наукового дослідження, становлять орієнтир у вивченні професійної культури, дозволять краще усвідомити нові цілі і завдання сучасної вищої освіти, обрати гнучкі організаційні форми навчання. Перспективу подальших досліджень убачаємо саме у вивченні компонентів професійної культури з метою розроблення моделі формування професійної культури майбутніх фахівців спеціальності «Дошкільна освіта».

\section{Література}

1. Вишнякова С. М.Профессиональное образование: словарь. Ключевые понятия, термины, актуальная лексика / С. М. Вишнякова. - Москва : НМЦ СПО, 1999. - 538 с. 2. Гончаренко С. Український педагогічний словник / С. Гончаренко. -Київ : Либідь, 1997. 206 с. 3. Исаев И. Ф. Профессионально-педагогическая культура преподавателя: [учеб. пособие для студ. высш. учеб. заведений] / И. Ф. Исаев. - Москва : Издательский центр «Академия», 2002. -208 с. 4. Маркова А. К. Психология труда учителя: [кн. для учителя] / А. К. Маркова. - Москва : Просвещение, 1993. - 192 с. 5. Ожегов С. И. Толковый словарь русского язика : 80000 слов и фразеологических выражений / С. И. Ожегов, Н. Ю. Шведова. - Росийская академия наук. Институт русского языка 
им. В. В. Виноградова. - [4-е изд., дополненное]. - Москва : ООО «А ТЕМП», 2006. - 944 с. 6. Селевко Г. К. Энциклопедия образовательных технологий: В 2 т. - Т. 1. - Москва : НИИ школьных технологий, 2006. - 816 с. 7. Синергетика і освіта: [монографія] / за ред. В. Г. Кременя. - Київ : Інститут обдарованої дитини, 2014. - 348 с. 8. Сластенин В. А. Введение в педагогическую аксиологию: [учеб. пособ. для студентов педагогических вузов] / $\quad$ В. А. Сластенин, Г. И. Чижакова. - Москва : Академия, 2003. - 192 с. 9. Коджаспирова Г. М. Словарь по педагогике / Г. М. Коджаспирова, А. Ю. Коджаспиров. Москва : ИКЦ «МарТ», 2005. - 448 с. 10. Философский энциклопедический словарь / Н. М. Ланда [и др.]. - Изд-во : Москва: Советская энциклопедия, 1983. - 840 с.

УДК 37.011.3-051:78

Володимир Костюков

\section{ДІАГНОСТИКА ФОРМУВАННЯ ПЕДАГОГІЧНО-АРТИСТИЧНИХ УМІНЬ МАЙБУТНІХ УЧИТЕЛІВ МУЗИКИ}

Костюков В. В. Діагностика формування педагогічно-артистичних умінь майбутніх учителів музики.

У статті розглянуто питання формування педагогічно-артистичних умінь майбутніх учителів музики в процесі фахового навчання. Виокремлено діагностувальний етап експериментальної роботи, який полягає в констатації вмінь використовувати можливості голосу, особистісної готовності до вияву артистичних здібностей, особистісного налаштування на вокальну роботу зі школярами. У результаті експериментальної роботи розроблено три рівні сформованості педагогічно-артистичних умінь студентів, а саме: високий, середній, низький. У результаті порівняння кількісної характеристики рівнів сформованості мотиваційно-пізнавального компонента на початковому етапі діагностики педагогічно-артистичних умінь з'ясовано, що серед майбутніх учителів музики виявлена переважна більшість студентів із низьким і середнім рівнями мотивації до оволодіння педагогічно-артистичними вміннями як основою педагогічної майстерності.

Ключові слова: педагогічно-артистичні вміння, діагностика, констатувальний експеримент, майбутній учитель музики.

Костюков В. В. Диагностика формирования педагогическо-артистических умений будущих учителей музыки.

В статье рассматриваются вопросы формирования педагогическо-артистических умений будущих учителей музыки в процессе профессионального обучения. Выделен диагностический этап экспериментальной работы, который заключался в констатации умений использовать возможности голоса, личностной готовности к проявлению артистических способностей, личностной настройки на вокальную работу со школьниками.

В результате экспериментальной работы разработаны три уровня сформированности педагогическо-артистических умений студентов, а именно: высокий, средний, низкий. В результате осуществления сравнения количественной характеристики уровней сформированности мотивационно-познавательного компонента на начальном этапе диагностики педагогическо-артистических умений установлено, что среди будущих учителей музыки обнаружено подавляющее большинство студентов с низким и средним уровнями мотивации к овладению педагогическо-артистическими умениями как основой педагогического мастерства. 